\title{
9 手術に伴う運用支援システム
}

〔はじめに〕本院手術部は, 平成 7 年 3 月に材料室業 務の運用支援として手術用セット器械收納用隇菌コン テナ（バクスター社製，以下コンテナ）女垂直式回転 ラック(ダイフク社製, CRP-10, 以下 VCR) とをコ ンピュータに連動したシステムを開発し，効率化と省 力化を試みたので概略と使用状況について報告する。

[概略】本システムは, 病院情報コンピュータより手 術患者情報をシステム内コンピュータに取り込み, 術 式とセット化されたコンテナとをVCR 内のバーコー ドリーダによって照合させ, 七ット器材の把握と在庫 管理を戝る，運用コンピュータは，既隇菌室と材料室 に設置して管理するとともに，この情報をLAN 回線 によって手術部内コンピュータに接続し,ネットワー ク情報として活用している.

コンテナは, フル, ミッド, ハーフ, クォータ, ミ この各サイズを合計 235 個使用した. 各コンテナとも セット化した手術器械・器具と診療科乱よび術式ごと に分類した情報をバーュード化し, 前面に各診療料ご
との認識プレートとともに設置した。

$\mathrm{VCR}$ は, 既減菌室にコンテナ収納用として 2 台, 未隇菌器材收納用として材料室に 1 台設置した. 既隇 菌室 VCR 2 台には, 各々にバーコードリーダを設置 し，自動的に収納コンテナ情報を読み取り，材料室と 既隇菌室の 2 台の運用コンピュータに情報を送信する 機能を有した。 また，収納棚は14段でミッドサイズの コンテナで約 100 個が収納できる. 材料室の VCR は, 幅 $3.0 \mathrm{~m}$ の 12 段で未隇菌手術器械・器具を各科ごとに 整理し收納できる機能を有する。

〔考察およびまとめ〕材料室に VCR 1 台を設置した ことにより収納面積の縮小化と動線の短縮が図れた。

コンテナを使用したことで器㧴のセット組が容易にな った. また，コンピュータ管理をしたことでセット器 材の内容拉よび減菌期限切れなどの管理が容易になる とともに回転率を調査することで適正器材管理につい ても把握できた。

\section{0 内視鏡手術器械の運用方法}

河村充洋, 和泉ちとき, 伊藤謙次, 井上博幸, 熊本良悟, 武智 誠, 大ケ瀬浩史, 大塚 壽, 小林展章 (愛媛大病院手術部)

内視鏡下手術は，低侵襲手術として，急速に普及し， その適応も扗大されている，当手術部においても，各 診療科に括けるその比率は近年特に増加し，昨年度は 全手術件数の約 $10 \%$ 占めている. それに伴い使用さ れるテレスコープや処置具も各科の用途に合わせた様 々な器械が導入されてきている.

しかし, 新しい機器や材料が次々と開発, 導入され ているなか, 内視鏡および処置具の使用後の洗浄，消 毒, 隇菌方法が標準化されていないのが現状である.

当施設では，使用頻度に比べて内視鏡機械の絶対数 が不足, 従来行ってさた EOG 隇菌, ホルマリンガス 消毒による患者や医療従事者に対する為害作用の可能 性, 機器の不完全な隇菌, 機器周囲環境の污染の可能
珄など，諸問題が発生している，さらに，機器の微細 部分と多種類にわたる処置具の清䒜維持管理が十分に 行えていないといら危惧もある.

今回，当施設に扣いて行われてきた，洗浄消毒，隇 菌の過程に強酸性水による洗浄, 消毒を加え, 新しく 購入したホルマリン隇菌器とコンテナシステムを使用 し, 術直後, 洗浄後, 隇菌後と機器の洗い出しにて検 体を採取，BBL セプティチェックにて $37^{\circ} \mathrm{C}, 1$ 週間 培養を行った，その結果，一般細菌においては，中央 材料部によるEOG 隇菌と同レベルの隇菌効果が得ら れた. またコンテナシステム使用により機器の散逸 を防ぎ，管理運用方法として有用であったので報告す る. 